Anais da Academia Brasileira de Ciências (2012) 84(3): 609-616

(Annals of the Brazilian Academy of Sciences)

Printed version ISSN 0001-3765 / Online version ISSN 1678-2690

www.scielo.br/aabc

\title{
Antioxidant activity and flavonoid content of Clusia fluminensis Planch. \& Triana
}

\author{
MARIA CAROLINA A. DA SILVA and SELMA R. PAIVA \\ Pós-Graduação em Ciências Aplicadas a Produtos para a Saúde, Laboratório de Botânica Estrutural e Funcional, \\ Departamento de Biologia Geral, Instituto de Biologia, Universidade Federal Fluminense, \\ Outeiro de São João Batista, s/n, Campus Valonguinho, 24020-140 Niterói, RJ, Brasil
}

Manuscript received on December 7, 2010; accepted for publication on December 16, 2011

\begin{abstract}
Clusia fluminensis Planch. \& Triana (Clusiaceae Lindl.) is a native species found in regions of high luminosity and water restriction. The aim of this study was to evaluate the antioxidant activity of Clusia fluminensis crude extracts through the scavenging of the stable free radical DPPH, and the determination of flavones and flavonols content in these extracts. The fruit acetonic extract showed the lowest $\mathrm{EC}_{50}$ value $(2.71 \pm 0.34 \mathrm{~g}$ extract / g DPPH), the lowest percentage of remaining DPPH at the concentrations of 125 and $250 \mu \mathrm{g} / \mathrm{mL}$ (about $4 \%$ in both), and also the greatest percentage of flavones and flavonols (13.93 $\pm 0.21 \%)$. Statistical analysis suggests a positive correlation between the presence of flavonoids and the antioxidant activity of this extract. From the obtained results it can be inferred that the acetonic extract of $C$. fluminensis fruits is an interesting target for the search of substances with antioxidant activity, especially flavonoids.
\end{abstract}

Key words: aluminum chloride, Clusia fluminensis, DPPH, flavonoids.

\section{INTRODUCTION}

In recent years, a growing number of evidences suggests the role of free radicals and other oxidants as the major cause of aging and degenerative diseases associated with it, such as cardiovascular diseases, inflammation, cerebral dysfunction and cancer (Ames et al. Aruoma 1994, Zarena and Sankar 2009). This led to an increasing interest in natural substances with antioxidant properties aiming to replace the synthetic antioxidants, which have been restricted due to their carcinogenic potential and because that can lead to increased liver mass and proliferation of endoplasmic reticulum (Degáspari and Waszczynskyj 2004).

Phenolic substances are characterized as natural antioxidants and have received much attention

Correspondence to: Maria Carolina Anholeti da Silva

E-mail: carolanholeti@gmail.com due to their role in the neutralization or scavenging of free radicals (Spencer et al. 2008), since their structure allows the donation of a proton to a free radical, interrupting the mechanism of oxidation. Because of this, the phenolic derivatives are transformed into free radicals. However, these radicals can be stabilized without promoting or propagating reactions (Ramalho and Jorge 2006).

Flavonoids and phenolic acids are classified as mixed antioxidants (Ramalho and Jorge 2006) because they are able to donate protons to free radicals, and are still capable of preventing the formation of reactive oxygen species (ROS) either by the inhibition of enzymes involved in the process, and by chelating metal traces involved in their production (Pietta 2000). The role of flavonoids as antioxidants has attracted interest to their 
pharmacological properties, especially those related to protection against cardiovascular diseases (Hertog et al. 1993, Kondo et al. 1996, Mazur et al. 1999).

Clusia fluminensis Planch. \& Triana is an endemic species of the Brazilian Atlantic Forest, occurring in the states of Bahia, Espírito Santo and Rio de Janeiro (Bittrich 2010). It is found in regions of high luminosity and water restriction, being widely used as an ornamental plant. It belongs to the Clusiaceae (Lindl.) family, which stands out by the description of it uses in folk medicine and by its great representativeness in Brazil (Fenner et al. 2006, Bittrich 2010, Reveal and Chase 2011). Among the main phenolic substances present in the species of the genus Clusia, flavonoids stand out, especially bi-flavonoids (Delle Monache 1991, Castro et al. 1999, Compagnone et al. 2008).

This study aimed to evaluate the antioxidant activity of Clusia fluminensis extracts through the scavenging of the stable free radical DPPH (1,1-diphenyl-2-picrylhydrazyl), as well as to determine the flavones and flavonols content in these extracts in order to verify the existence of a possible relationship between them.

\section{MATERIALS AND METHODS}

\section{REAGENTS AND EQUIPMENTS}

All solvents used were of analytical grade and obtained from VETEC, Brazil. The DPPH radical and rutin were purchased from Sigma, and commercial BHT (butylated hydroxytoluene) was obtained from Purifarma. Recordings were made by a UV-VIS spectrometer Biospectro SP-220 (Curitiba, Brazil).

Plant MATERIAL

For the present study, leaves and stems from a male individual and fruits from a female individual of Clusia fluminensis Planch \& Triana were collected at Forte Barão do Imbuhy, Niterói, in Rio de Janeiro State, Brazil. Leaves, stems and partially ripe fruits were collected in the autumn, and completely ripe fruits were collected in the winter. The plant material was identified by Dr. Marcelo Guerra Santos, and a voucher specimen was deposited at the herbarium of the Faculdade de Formação de Professores, Universidade do Estado do Rio de Janeiro (RFFP), Brazil, registered under the number 9213.

\section{PREPARATION OF Plant EXTRACTS}

Leaves, fruits and stems of $C$. fluminensis were dried in an oven at $40^{\circ} \mathrm{C}$ and subsequently fragmented. The methanolic extracts of leaves, stems and fruits and the acetonic extracts of fruits and stems of C. fluminensis were obtained by static maceration of plant organs with the respective solvents at room temperature for 30 days for methanolic extracts and 15 days for acetonic extracts. The solvent was renewed at each seven days and followed by evaporation under reduced pressure.

\section{DETERMINATION OF TOTAL ANTIOXIDANT ACTIVITY}

Total antioxidant activity (TAA) was evaluated by spectrophotometric method based on the scavenging of the free radical DPPH (1,1-diphenyl2-picrylhydrazyl) according to the methodologies proposed by Mensor et al. 2001 and Rufino et al. 2007, with some modifications.

\section{Construction of the calibration curve of DPPH}

It was prepared a solution of the radical DPPH $0.3 \mathrm{mM}$ in methanol, which was then diluted providing solutions with final concentrations of 30 , $60,120,150$ and $180 \mu \mathrm{M}$. In a dark room, an aliquot of each solution of DPPH obtained was transferred to the spectrophotometer cuvettes, and the readings were performed at $518 \mathrm{~nm}$. Methanol was used as blank to calibrate the spectrophotometer. The calibration equation was obtained by linear regression of plots, where the abscissa represented the concentration of different solutions and the ordinate the corresponding absorbances. 


\section{Readings of sample absorbances}

Sample stock solutions of the extracts $(1.0 \mathrm{mg} / \mathrm{mL}$ in methanol) were diluted providing solutions with final concentrations of 250,125, 50, 25, 10 and 5 $\mu \mathrm{g} / \mathrm{mL}$. $1.0 \mathrm{~mL}$ of DPPH solution $(0.3 \mathrm{mM})$ was added to aliquots of $2.5 \mathrm{~mL}$ of different solutions of each extract. The mixture was homogenized in a vortex agitator. It was used $2.5 \mathrm{~mL}$ of methanol and $1.0 \mathrm{~mL}$ of DPPH solution as negative control, and $2.5 \mathrm{~mL}$ of a diluted solution from each extract with $1.0 \mathrm{~mL}$ of methanol as blank. The absorbance was read at $518 \mathrm{~nm}$ and monitored at every 5 minutes during 30 minutes, when it was performed the reading of the final absorbance to calculate the concentration of sample required to reduce in 50\% the initial concentration of DPPH $\left(\mathrm{EC}_{50}\right)$, expressed as g sample / $\mathrm{g}$ DPPH, as described by Rufino et al. 2007. It was used BHT (butylated hydroxytoluene) as positive control, which was submitted to the same procedures mentioned for the extracts. All procedures were performed in triplicate.

\section{Determination of $E C_{50}$}

After the readings, the value corresponding to half the absorbance of the negative control was replaced in the calibration equation in order to find the consumption of DPPH $(\mu \mathrm{M})$ corresponding to a reduction of $50 \%$ in its initial concentration, and then this value was converted to $\mathrm{g} / \mathrm{L}$ of DPPH using the following formula: $[\mathrm{DPPH}](\mathrm{g} / \mathrm{L})=[\mathrm{DPPH}(\mu \mathrm{M})] / 1.000 .000) \mathrm{x}$ 394.3 (molecular weight of DPPH).

It was obtained a new equation by linear regression of plots for each extract where the abscissa represented different concentrations of solutions from plant extracts and the ordinate the corresponding absorbances. Only the points that were within the range of linearity (at least 3 points) were used.

To calculate the TAA, the value corresponding to half the initial absorbance of the negative control was then replaced in each extract equation in order to find the concentration of extract required to reduce in $50 \%$ the initial concentration of DPPH $\left(\mathrm{EC}_{50}\right)$.

The $\mathrm{EC}_{50}$ value found $(\mu \mathrm{g} / \mathrm{mL})$ was divided by 1.000 in order to obtain the value in $\mathrm{g} / \mathrm{L}$ of extract, and then it was divided by the value found in $\mathrm{g} / \mathrm{L}$ of DPPH to obtain the final result expressed in $g$ extract/g DPPH:

$$
\mathrm{EC}_{50}\left(\text { extract }(\mathrm{g}) / \mathrm{DPPH}(\mathrm{g})=\frac{\mathrm{EC}_{50}(\mu \mathrm{g} / \mathrm{mL}) / 1.000}{\mathrm{DPPH}(\mathrm{g} / \mathrm{L})}\right.
$$

\section{Evaluation of reaction kinetics}

The kinetic behavior of the reaction with DPPH was evaluated by a dose-response curve related to the decrease in the percentage of remaining DPPH in function of time for each extract concentration. The average of the absorbances read in triplicate at each 5 minutes was converted into the concentration of remaining DPPH $\left[\mathrm{DPPH}_{\mathrm{rem}}\right]$ using the calibration equation of DPPH. The initial concentration of $\mathrm{DPPH}\left[\mathrm{DPPH}_{0}\right]$ was obtained from the absorbance of the negative control using the same equation. These values were then used to obtain the percentage of remaining DPPH $\left(\% \mathrm{DPPH}_{\text {rem}}\right)$ according to the formula: $\% \mathrm{DPPH}_{\mathrm{rem}}=\left[\mathrm{DPPH}_{\mathrm{rem}}\right] /\left[\mathrm{DPPH}_{0}\right] \times 100$.

\section{DETERMINATION OF FLAVONOIDS CONTENT}

The content of flavonoids, expressed as flavones and flavonols, was determined in the methanolic and acetonic extracts of Clusia fluminensis using the colorimetric method involving reaction with aluminum chloride, as described by Chang et al. 2002, with modifications.

\section{Construction of the calibration curve}

It was prepared a stock solution of rutin $(1.5 \mathrm{mg} /$ $\mathrm{mL}$ in $95 \%$ ethanol), which was diluted providing solutions with final concentrations of 30,60 , and $90 \mu \mathrm{g} / \mathrm{mL}$. It was added $1.5 \mathrm{~mL}$ of $95 \%$ ethanol, $0.1 \mathrm{~mL}$ of potassium acetate $1 \mathrm{M}, 2.8 \mathrm{~mL}$ of distilled water and $0.1 \mathrm{ml}$ of aluminum chloride 
(10\% in distilled water) to an aliquot of $0.5 \mathrm{~mL}$ of each prepared solution. The reaction mixtures were homogenized in a vortex agitator, and after 30 min of incubation at room temperature they had their absorbances read in a spectrophotometer at $415 \mathrm{~nm}$. For the blank, the volume of aluminum chloride $10 \%$ was replaced by distilled water. The calibration equation was obtained by linear regression of plots, where the abscissa represented different concentrations of rutin and the ordinate the corresponding absorbances.

\section{Sample preparation}

$10 \mathrm{mg}$ of each extract were dissolved in $2.5 \mathrm{~mL}$ of $95 \%$ ethanol and then stirred for 5 minutes in a vortex agitator. The resulting solution was filtered and the solid residue dissolved in $2.5 \mathrm{~mL}$ of $95 \%$ ethanol, and again stirred for 5 minutes and filtered. The volumes of the filtrates were combined, and the final solution volume was adjusted to $5 \mathrm{~mL}$ with $95 \%$ ethanol.

\section{Readings of sample absorbances}

An aliquot of $0.5 \mathrm{~mL}$ of each extract solution was subjected to the same procedure applied to the rutin solutions, as described above. Readings were performed in triplicate.

\section{Calculation of flavonoids content}

After the readings, the absorbance values of each extract solution were replaced in the rutin calibration equation, providing the content of total flavonoids expressed as rutin equivalents in $\mu \mathrm{g} / \mathrm{mL}$. To express the results as a percentage of flavonoids, it was used the formula:

$\%$ Flavonoids $=\frac{\begin{array}{c}{[\text { flavonoids }](\mu \mathrm{g} / \mathrm{mL}) \times \text { total volumn }} \\ \text { of ethanolic extract }(\mathrm{mL})\end{array}}{\text { mass of extract }(\mu \mathrm{g}) \times 100}$

STATISTICAL ANALYSIS

The results were expressed as mean \pm standard deviation of three independent experiments, and the comparison among the three means was performed using the one-way analysis of variance (ANOVA). ANOVA test was also performed among the results obtained for each sample. Pearson's correlation test was performed between the percentages of the total antioxidant activity and flavonoid content.

\section{RESULTS AND DISCUSSION}

Although it does not represent similar conditions to the processes that occur in vivo, the colorimetric method to evaluate the ability of scavenging the stable free radical DPPH represents a simple and rapid method to detect the presence of substances with antioxidant properties in crude plant extracts in order to become targets of bioguided assays, aiming the isolation of such substances.

Table I shows the EC50 values and flavonoid content found for the extracts of $C$. fluminensis. The curves obtained by linear regression showed a good coefficient of determination $\left(\mathrm{r}^{2}>0.80\right)$, and the statistical treatment of data by ANOVA showed no significant differences among the three independent experiments performed for each extract $(p \geq 0.05)$.

TABLE I

EC $_{50}$ values and flavonoid content of Clusia fluminensis crude extracts.

\begin{tabular}{ccc}
\hline Samples & $\mathbf{E C}_{\mathbf{5 0}}(\mathbf{g}$ extract/g DPPH $)$ & Flavonoid content (\%) \\
\hline Leaves methanolic crude extract & $3.48 \pm 0.13$ & $8.07 \pm 1.70$ \\
Fruits methanolic crude extract & $4.84 \pm 0.40$ & $10.68 \pm 0.58$ \\
Stems methanolic crude extract & $3.28 \pm 0.20$ & $9.82 \pm 0.53$ \\
Fruits acetonic crude extract & $2.71 \pm 0.34$ & $13.93 \pm 0.21$ \\
Stems acetonic crude extract & $4.56 \pm 0.26$ & $9.12 \pm 1.14$ \\
\hline
\end{tabular}


The analysis of Table I shows that $\mathrm{EC}_{50}$ values of all extracts are greater than the value found for BHT $(0.53 \pm 0.04 \mathrm{~g} \mathrm{BHT} / \mathrm{g} \mathrm{DPPH})$. However, it is important to emphasize that they are crude extracts composed by various substances, and the antioxidant activity can be a response to both a synergistic effect of these substances and the presence of a specific substance with high antioxidant capacity.
From the point of view of reaction kinetics, it was observed that all extracts showed an almost instantaneous response at each concentration tested since the percentage of the remaining DPPH at the beginning of the reaction remains almost constant during the thirty minutes of monitored reaction. This is a different pattern from the one observed for BHT, which only behaves this way in the two highest concentrations analyzed (Figure 1).

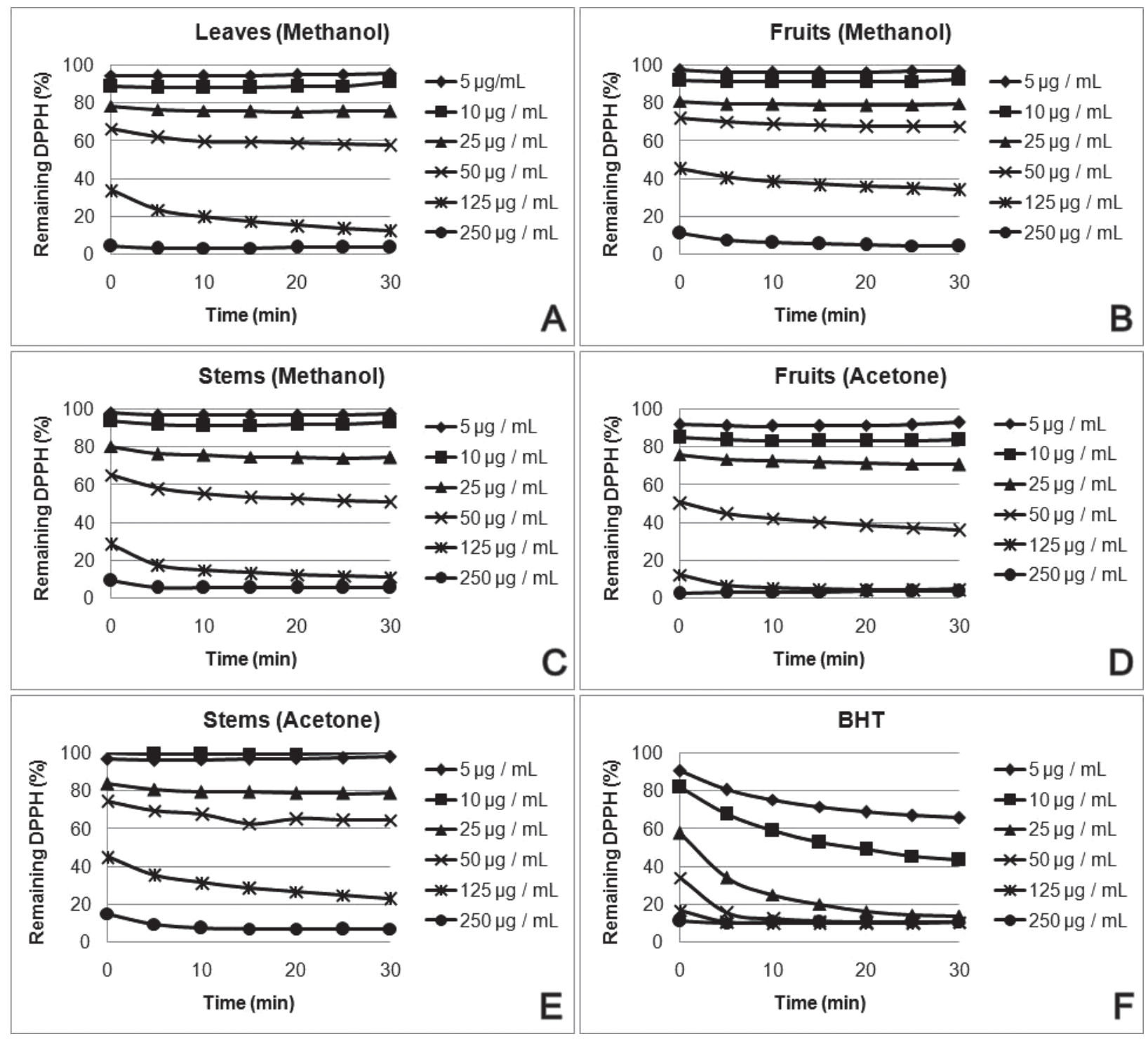

Fig. 1 - Reaction kinetics. (A) Methanolic crude extract of leaves of C. fluminensis with DPPH; (B) methanolic crude extract of fruits of C. fluminensis with DPPH; (C) methanolic crude extract of stems of $C$. fluminensis with DPPH; (D) acetonic crude extract of fruits of $C$. fluminensis with DPPH; (E) acetonic crude extract of stems of C. fluminensis with DPPH; (F) BHT with DPPH. 
The analysis of Figure 1 shows that at the concentration of $25 \mu \mathrm{g} / \mathrm{mL}$ BHT reaches after thirty minutes its maximum antioxidant activity, with approximately $10 \%$ of remaining $\mathrm{DPPH}$, and this maximum value is maintained at the concentrations of 50,125 and $250 \mu \mathrm{g} / \mathrm{mL}$ with a decrease just in the time required to achieve it as the concentration increases. Among the extracts analyzed (Figure 1), the fruit acetonic extract showed not only the lowest $\mathrm{EC}_{50}$ value, but also the lowest percentage of remaining DPPH at 125 and $250 \mu \mathrm{g} / \mathrm{mL}$ (about $4 \%$ in both). The methanolic extracts of leaves and stems reached approximately $10 \%$ of remaining DPPH at $125 \mu \mathrm{g} / \mathrm{mL}$, and 4 and $5 \%$ respectively at $250 \mu \mathrm{g} / \mathrm{mL}$. The fruits methanolic extract and stems acetonic extract also showed a percentage of remaining DPPH lower than that of BHT at $250 \mu \mathrm{g} /$ $\mathrm{mL}$ (5 and 7\%, respectively).

The DPPH assay is based on the scavenging of the free radical 2,2-diphenyl-1-picrylhydrazyl (DPPH), which is reduced after the reaction with proton donor substances (Sánchez-Moreno 2002). The methanolic and acetonic extracts have high and mean polarity character, respectively, which favors the presence of phenolic substances such as flavonoids, whose antioxidant activity has been largely investigated in recent years (Chen et al. 1996, Van Acker et al. 1996, Cao et al. 1997, Heim et al. 2002, Seyoum et al. 2006).

The principle of the method used for the determination of the flavonoid content consists in the fact that aluminum chloride forms stable acid complexes with the carbonyl group at $\mathrm{C} 4$ and hydroxyls at C3 (flavonols) and C5 in flavonols and flavones, besides forming labile acid complexes with hydroxyls in the ortho position in A or B rings of flavonoids (Chang et al. 2002).

Chang and coworkers (2002) also showed that the presence of an unsaturation between $\mathrm{C} 2$ and $\mathrm{C} 3$ in the $\mathrm{C}$ ring of flavonoids favors a maximum absorption of the complex formed with aluminum chloride in the range of $415-440 \mathrm{~nm}$, since the complexes formed with flavanones and flavanonols, which have no such unsaturation, result in a very low absorbance at this wavelength range. Similar results were demonstrated for isoflavones, whose complexes also showed no significant absorbance. This same unsaturation is also responsible for a better antioxidant activity of flavones and flavonols because it favors the conjugation between $\mathrm{C}$ and $\mathrm{B}$ rings, and the carbonyl group at $\mathrm{C} 4$, contributing to the stabilization of the flavonoid radical formed by the abstraction of a hydrogen atom from a hydroxyl group that is usually in the position 4 of the $\mathrm{B}$ ring (Pietta 2000, Seyoum et al. 2006).

The ANOVA test performed between the samples showed no significant differences between the $\mathrm{EC}_{50}$ values of stems methanolic extract and fruits acetonic extract, which showed the best antioxidant activity as presented in Table I, However, a greatest percentage of flavones and flavonols was found in the fruits acetonic extract $(13.93 \pm 0.21 \%)$. The statistical analysis also showed that a significant difference was observed when comparing the flavonoid content of the fruits acetonic extract with the leaves methanolic extract, stems acetonic extract and fruits methanolic extract. The Pearson's correlation test showed a slight positive correlation between the total flavonoid content and the antioxidant activity of the extracts of Clusia fluminensis. Zarena and Sankar (2009) evaluated the antioxidant activity of different extracts of the fruits pericarp of Garcinia mangostana L. (Clusiaceae), and demonstrated that acetone and ethyl acetate were the most effective solvents in the extraction of substances with antioxidant activity. The results obtained for Clusia fluminensis showed no significant differences between the total flavonoid content of the acetonic and methanolic extracts of the fruits. However, there was a very significant difference between the $\mathrm{EC}_{50}$ values of both extracts, in which the acetonic extract showed an $\mathrm{EC}_{50}$ value of almost 2 times smaller than the methanolic extract. These results, 
together with the results mentioned above, suggest that the substances with best antioxidant activity in fruits of species of Clusiaceae have probably an intermediate polarity character.

It was observed a different situation with the extracts of stems. The methanolic extract showed no significant differences in the percentage of flavonoids $(9.82 \pm 0.53 \%)$ when compared with the acetonic extract $(9.12 \pm 1.14 \%)$. However, they showed a significant difference in the $\mathrm{EC}_{50}$ values, with a lower $\mathrm{EC}_{50}$ value for the methanolic extract (Table I), showing that in stems of $C$. fluminensis the substances with the best antioxidant activity have probably a high polarity character.

The methanolic extract of leaves showed the lowest percentage of flavonoids among the analyzed extracts $(8.07 \pm 1.70 \%)$. However, this difference is only significant when compared with the acetonic extract of fruits. It showed the third better $\mathrm{EC}_{50}$ value for the antioxidant activity, which is statistically similar to the value obtained for the methanolic extract of the stems (second best value for $\mathrm{EC}_{50}$ ). It suggests that in this case the antioxidant activity is not directly related to the concentration of flavonoids, and might be a result of the type of flavonoid involved or the presence of other substances with antioxidant activity not represented by flavonoids.

\section{CONCLUSION}

This study showed that the extracts of Clusia fluminensis are sources of substances with free radicals scavenger activity. The results were compared with the percentage of flavonoids in these extracts, and the statistical analysis showed a positive correlation between these parameters. Among all the extracts analyzed, the fruits acetonic extract was found to be the most effective in terms of antioxidant activity, and also the extract with the highest percentage of flavonoids. This suggests that acetone is an efficient solvent in the extraction of antioxidant substances, and makes this extract a target for further studies aiming at the chemical characterization of such substances.

\section{ACKNOWLEDGMENTS}

The authors thank Fundação Carlos Chagas Filho de Amparo à Pesquisa do Estado do Rio de Janeiro (FAPERJ) for financial support, and the team of undergraduate students, Priscila Barros, Mariana Ribeiro, Beatriz Andrade, Emilson Barreto Junior and Felipe Pinheiro, for their help during the assays.

\section{RESUMO}

Clusia fluminensis Planch. \& Triana (Clusiaceae Lindl.) é uma espécie nativa encontrada em regiões de alta luminosidade e restrição hídrica. O objetivo deste estudo foi avaliar a atividade antioxidante dos extratos brutos de Clusia fluminensis através do sequestro do radical livre estável DPPH, e a determinação do conteúdo de flavonas e flavonóis nesses extratos. O extrato acetônico dos frutos apresentou o menor valor de $\mathrm{EC}_{50}(2,71 \pm$ $0,34 \mathrm{~g}$ extrato / g DPPH), o menor percentual de DPPH remanescente nas concentrações de 125 e $250 \mu \mathrm{g} / \mathrm{mL}$ (aproximadamente 4\% em ambos), e também o maior percentual de flavonas e flavonóis $(13,93 \pm 0,21 \%)$. Análise estatística sugere uma correlação positiva entre a presença de flavonóides e a atividade antioxidante do extrato. A partir dos resultados obtidos pode ser sugerido que o extrato acetônico dos frutos de C. fluminensis é um alvo interessante para a busca de substâncias com atividade antioxidante, especialmente flavonóides.

Palavras-chave: cloreto de alumínio, Clusia fluminensis, DPPH, flavonóides.

\section{REFERENCES}

Ames BN, Shigenaga MK And Hagen TM. 1993. Oxidants, antioxidants, and the degenerative diseases of aging. Proc Natl Acad Sci USA 90: 7915-7922.

ARUOMA OI. 1994. Nutrition and health aspects of free radicals and antioxidants. Food Chem Toxicol 32: 671-683.

BitTrich V. 2010. Clusiaceae in Lista de Espécies da Flora do Brasil. Jardim Botânico do Rio de Janeiro. Available at: http://floradobrasil.jbrj.gov.br/2010/FB000089. Accessed on 23 August 2010. 
CAO G, SOFIC E AND Prior RL. 1997. Antioxidant and prooxidant behavior of flavonoids: Structure-activity relationships. Free Radic Biol Med 22: 749-760.

Castro O, Gutiérrez JM, Barrios M, Castro i, Romero M AND UMAÑA E. 1999. Neutralización del efecto hemorrágico inducido por veneno de Bothrops asper (Serpentes: Viperidae) por extractos de plantas tropicales. Rev Biol Trop 47: 605-615.

Chang C-C, YAng M-H, Wen H-M AND Chern J-C. 2002. Estimation of total flavonoid content in propolis by two complementary colorimetric methods. J Food Drug Anal 10: 178-182.

CHEN ZY, CHAN PT, Ho KY, FUnG KP AND WANG J. 1996. Antioxidant activity of natural flavonoids is governed by number and location of their aromatic hydroxyl groups. Chem Phys Lipids 79: 157-163.

Compagnone RS, Suarez AC, Leitão SG and Delle MONACHE F. 2008. Flavonoids, benzophenones and a new euphane derivative from Clusia columnaris Engl. Rev Bras Farmacogn 18: 6-10.

DEGÁSPARI CH AND WASZCZYNSKYJ N. 2004. Propriedades antioxidantes de compostos fenólicos. Visão Acadêmica 5: $33-40$.

Delle Monache F. 1991. Flavonoids C-glycosides from Clusia sandiensis. Rev Latinoamer Quim 22: 27-29.

Fenner R, Betti AH, Mentz LA And Rates SMK. 2006. Plantas utilizadas na medicina popular brasileira com potencial atividade antifúngica. Rev Bras Cienc Farm 42: 369-394.

HeIM KE, TAGLIAFERRO AR AND BoBILYA DJ. 2002. Flavonoid antioxidants: Chemistry, metabolism and structureactivity relationships. J Nutr Biochem 13: 572-584.

Hertog MGL, Feskens EJM, Kromhout D, Hollman PCH AND KATAN MB. 1993. Dietary antioxidant flavonoids and risk of coronary heart disease: The Zutphen elderly study. The Lancet 342: 1007-1011.

KONDO K, HIFANO R, MATSUMOTO A, IGARASHI O AND ITAKURA H. 1996. Inhibition of LDL oxidation by cocoa. The Lancet 348: 151a.
Mazur A, BAYle D, LAB C, Rock E AND RAYSSIGUIER Y. 1999. Inhibitory effect of procyanidin-rich extracts on LDL oxidation in vitro. Atherosclerosis 145: 421-422.

Mensor LL, Menezes FS, Leitão GG, ReIs AS, Dos SAntos TC, Coubel CS AND LEITÃo SG. 2001. Screening of Brazilian plant extracts for antioxidant activity by the use of DPPH free radical method. Phytother Res 15: 127-130.

PIETTA PG. 2000. Flavonoids as antioxidants. J Nat Prod 63: $1035-1042$.

RAMALHO VC AND JORGE N. 2006. Antioxidants used in oils, fats and fatty foods. Quim Nova 29: 755-760.

REVEAL JL AND CHASE MW. 2011. APG III: Bibliographical information and synonymy of Magnoliidae. Phytotaxa 19: 71-134.

Rufino MSM, Alves RE, Brito ES, Morais SM, SAMPAIO CG, PÉREZ-Jiménez J AND SAURA-CALIXTO FD. 2007. Determinação da atividade antioxidante total em frutas pela captura do radical livre DPPH. Fortaleza: Embrapa Agroindústria Tropical - Comunicado Técnico [Online]. Available at: http://www.cnpat.embrapa.br/cnpat/cd/jss/ acervo/Ct_127.pdf. Accessed on 29 June 2009.

SÁNCHEZ-MORENO C. 2002. Review: Methods used to evaluate the free radical scavenging activity in foods and biological systems. Food Sci Technol Int 8: 121-137.

SEYOUM A, ASRES K AND EL-FIKY FK. 2006. Structure-radical scavenging activity relationships of flavonoids. Phytochemistry 67: 2058-2070.

SPENCER JPE, MOHSEN MMAE, MiniHANE AM AND MATHERS JC. 2008. Biomarkers of the intake of dietary polyphenols: strengths, limitations and application in nutrition research. Br J Nutr 99: 12-22.

VAn Acker SABE, VAN Den Berg D-J, Tromp MNJL, GRIFFIOEN D, VAN BENNEKOM WP, VAN DER VIJGH WJF AND BAST A. 1996. Structural aspects of antioxidant activity of flavonoids. Free Radical Bio Med 20: 331-342.

ZARENA AS AND SANKAR KU. 2009. A study of antioxidant properties from Garcinia mangostana L. pericarp extract. Acta Sci Pol Technol Aliment 8: 23-34. 